\title{
Antecedents of early terminations in franchising: franchisor versus franchisee cancelations
}

\author{
Begoña López-Fernández • Susana López-Bayón
}

Accepted: 10 January 2017

(C) Springer Science+Business Media New York 2017

\begin{abstract}
Franchisors capitalize on franchisee entrepreneurial capacity to grow. However, enabling franchisees to develop their ventures may damage system consistency. This dilemma makes conflict particularly prevalent in the field of franchising. Nevertheless, prior research has reported an incomplete picture of factors leading to serious disagreement and premature termination in franchise partnerships. We address this gap, first, by adding the entrepreneurial autonomy of franchisees as a relevant but underexplored source of conflict and, second, by providing a more fine-grained analysis of franchisors' versus franchisees' drivers of termination. Specifically, we focus on the controversial issues of pricing and local advertising policies and analyze how expanding franchisees' entrepreneurial autonomy in these decision areas is related to contract terminations depending on who ended the relationship (the franchisor or a franchisee). The study also highlights less controversial requirements and conditions (e.g., upfront investments, franchisor experience ...) that may reduce early terminations. Our empirical objectives are met by using survey data from a sample of franchisor companies. The results show how the performance outcomes of entrepreneurial autonomy differ depending on the
\end{abstract}

B. López-Fernández $(\bowtie) \cdot S$. López-Bayón Business Administration Department, Facultad de Economía y Empresa, University of Oviedo, Avda. del Cristo s/n, 33071 Oviedo, Asturias, Spain

e-mail: blopez@uniovi.es

S. López-Bayón

e-mail: sbayon@uniovi.es decision area in which it is exercised. Results also throw light on the consequences of various critical franchise policies that may be masked if both types of termination (franchisors vs. franchisees) are considered together.

Keywords Franchise relationship · Early terminations . Conflict $\cdot$ Entrepreneurial autonomy

JEL classification $\mathrm{L} 14 \cdot \mathrm{L} 22 \cdot \mathrm{M} 21 \cdot \mathrm{M} 13$

\section{Introduction}

Relationships with external partners are considered an important tool for improving SME knowledge and capabilities (Szarka 1990; Street and Cameron 2007; Bocconcelli et al. 2016). However, although external partners may help SMEs to enhance their competitive advantage and entrepreneurial success (Stuart et al. 1999; Stuart 2000; Elfring and Hulsink 2003; Arend 2006; Bi et al. 2017), they may also result in conflict, with firms losing control over their businesses and failing to meet their expectations. As a consequence, the entrepreneurship and small business literature has recognized the need to investigate the risks associated with engaging in external relationships and the conditions under which relationships may fail (Street and Cameron 2007).

Prior studies, however, have so far reported an incomplete picture of factors leading to serious conflict and unplanned termination in inter-firm alliances (Bakker 2016, Dan and Zondag 2016). This paper develops this research line by examining the factors that 
lead to premature terminations in the particular setting of franchise agreements.

The study is based on the idea that franchising represents an entrepreneurial team between two dissimilar entrepreneurs, franchisor, and franchisees (Kaufmann and Dant 1999; Clarkin and Rosa 2005; Combs et al. 2011). Together, they expand a business concept in extensive markets, but they differ in their roles and particular interests. On the one hand, franchisees benefit from a differentiated business and the time-tested knowhow of the franchisor (Michael 1999b). Specifically, franchising facilitates jump-start entrepreneurial activities by providing SMEs with competitive awareness and appropriate knowledge (Paswan and Rajamma 2016) and may even facilitate economic development in their regions (Michael 2014). On the other hand, franchisors benefit from the franchisees' management capabilities and specific local know-how in the running of their outlets (Kaufmann and Eroglu 1999; Sorenson and Sørensen 2001) that helps them to overcome entrepreneurial capacity shortages (Norton 1988).

The role of franchisors, as owners and creators of the business concept, is to lay down the terms and conditions that apply to franchisees' responsibility, in order to protect system-wide standards (e.g., brand name stability). However, this may be tricky because the two partners may disagree on certain provisions which, although pursuing homogeneity and preventing deviations, may also lead to serious conflict and eventual contract terminations. Actually, the very complexity of the franchise relationship makes conflict especially prevalent in this setting (Spinelli and Birley 1998; Winsor et al. 2012).

For our purpose, franchise conflict is conceptualized as problematic differences arising between franchisor and franchisees in response to obstacles that pose a threat to the achievement of their respective goals (Weaven et al. 2010). But only serious conflict and disputes end up in early terminations as a last resort solution (Winsor et al. 2012). Prior research has reported significant franchise termination rates, to the extent that lawmakers have considered information on terminations necessary for making a sound decision on the purchase of a particular franchise license (Clarkin 2008). ${ }^{1}$

\footnotetext{
${ }^{1}$ For instance, US regulation compels franchisors to reveal the number of early terminations in their systems during recent years in the Uniform Franchise Offering Circular (UFOC) (Clarkin 2008). Similarly, Spanish law obliges franchisors to include this information in the precontractual documents sent to prospects.
}

Nevertheless, the key factors that lead to serious conflict and relationship terminations in franchising remain underexplored. Previous work is based on case studies and/or interviews with rich qualitative information (Frazer and Winzar 2005; Weaven et al. 2010; Winsor et al. 2012) and highlights the importance of franchisor-franchisee fit. This involves, for franchisors, recruiting suitable franchisees and, for franchisees, joining a franchise chain congruent with personal goals and abilities. Extant research has also explored various contextual factors affecting terminations, such as industry, system size, or growth (Holmberg and Morgan 2003), and also relates terminations to franchisor support and life cycle (Frazer 2001).

Although the above insights are useful, they have generally overlooked two important issues: (i) the influence of the entrepreneurial autonomy of franchisee firms as a significant driver of terminations and (ii) the potential differences between franchisor and franchisees in their reactions to conflict prevention strategies.

To address these gaps, drawing on agency and resource-based theories, the paper examines the aftermath of two different sets of policies in terms of their capacity to explain franchise terminations. One set builds on the findings of Michael and Combs (2008) and is composed of policies aiming to prevent agency problems (and reduce failure), such as training programs, or experience requirements. Our prediction is that these will have the same impact on franchisors and franchisees in terms of serious conflict and early terminations generated within the system. The other set deals with the degree of entrepreneurial autonomy of franchisees; namely, the extent to which the franchisees are able to freely decide how to operate their outlets outside the standardized confines of the franchise system (Dada 2016). Autonomy provides franchisees with the freedom and flexibility they need for entrepreneurial activities (i.e., risk-taking, innovative, and proactive initiatives) (Lumpkin et al. 2009). However, although the franchisor's autonomy is usually undisputed, that of franchisees is debatable (Grünhagen et al. 2014; Dada 2016). We specifically examine franchisees' autonomy in two decision areas, pricing and local advertising. We consider the delegation of these policies as controversial issues and analyze how decentralizing them may impact contract terminations differently, depending on whether these are initiated by the franchisor or a franchisee.

Building on these arguments, and using franchisors' survey data, the study contributes to the literature in 
several ways. First, we address the still limited research regarding how entrepreneurial autonomy may drive performance in entrepreneurial teams (i.e., franchise networks). Even though autonomy has been considered basic for stimulating entrepreneurial orientation and value creation (Lumpkin et al. 2009; Wales et al. 2013), only a few studies have examined the relationship between entrepreneurial autonomy and business performance (a recent contribution is Karimi and Walter 2016). Moreover, they have rarely tackled the negative impacts of autonomy on performance. In addition, most studies of entrepreneurial autonomy are limited to a firm-level analysis and neglect this entrepreneurial dimension beyond the company boundaries. We extend the research to the supra-level of inter-firm networks, and analyze how different autonomy profiles within entrepreneurial teams may explain failure.

Second, with the exception of a few exploratory studies (e.g., Frazer and Winzar 2005; Weaven et al. 2010), most research on franchise conflict analyzes the sources and effects of conflict on only one side of the dyad: either the franchisees or the franchisor (e.g., Davies et al. 2011; Winsor et al. 2012; Weaven et al. 2014; Kang and Jindal 2015; López-Bayón and LópezFernández 2016). However, the franchise network is a community of mutually dependent entrepreneurs, in which franchisees are distinct entities with autonomy and innovative aspirations (Davies et al. 2011). Consequently, it is important to analyze both franchisors' and franchisees' concerns (Dant 2008) to avoid providing only a partial account of the underlying basis of franchise conflict. This study addresses this gap, disentangling the different impacts that the allocation of various decisions rights (i.e., pricing and local advertising) may have on franchisors vs. franchisee terminations. Thus, the study demonstrates that the extent to which entrepreneurial autonomy may influence early terminations depends not only on the decision area in which it is exercised (López-Bayón and LópezFernández 2016) — in our case, pricing vs. local advertising decisions - but also on who terminates the relationship (i.e., the franchisees or the franchisor). Moreover, we provide new evidence on how franchisees and franchisors react differently to various policies considered in the literature as conflict preventers (e.g., training policies and previous experience requirements).

The rest of the paper is organized as follows. The next section presents the conceptual framework and research hypotheses. The following sections describe the research design and the empirical results. The final section offers implications for researchers and practitioners.

\section{Theory and hypotheses}

Franchisors draft their contracts with the aim of achieving consistency within the firm and minimizing agency problems. However, franchising agreements are necessarily incomplete because they govern long-term, ongoing relationships that cannot be perfectly foreseen (Hadfield 1990; Hendrikse et al. 2015; Solís-Rodríguez and González-Díaz 2016). As Hadfield puts it, contracts are "broad in scope, but short on detail" (1990, p. 991). Even so, very often franchisees neither read the contract nor follow it closely in daily operations (Bradach 1998; Clarkin and Rosa 2005).

In principle, franchisors have developed the brand and are in charge of updating it. But franchisees also introduce revisions of the original model when implementing it. Franchisees, as entrepreneurs, seek the best return on their investments and are highly committed to success. Sometimes, when seeking new opportunities, they introduce novelties. For these reasons, franchisors provide entrepreneurial autonomy in certain fields where there may be potential advantages from adapting to the environment. These are the peripheral aspects of the business (Kaufmann and Eroglu 1999) that do not compromise the homogeneity of the brand, but may ultimately enhance franchisees' local adaptive capacity (Winter et al. 2012) and their motivation by meeting their entrepreneur's desire for autonomy (Dant and Gundlach 1999). Moreover, as franchisees contribute to growth, franchisors tend to recruit prospects that are likely to behave more like entrepreneurs than investors (Zachary et al. 2011).

However, there is a trade-off between tailoring products and services to particular environments and the threat of contractual hazards. These hazards come from mistakes, opportunism, and costly monitoring.

Franchisees may modify the business concept detrimentally if they overestimate the degree of idiosyncrasy of their demand or if they underestimate the complexity that underlies the building of goodwill (Winter et al. 2012). Additionally, some franchisees may behave opportunistically, trying to save costs at the expense of service quality. Such behavior may be individually rewarding if spillover effects are in place and customers 
do not always patronize the same outlet. Finally, delegation of decision rights raises the costs of monitoring and enforcing quality standards because it will be more difficult to prove contract violations when outlets become more diverse and benchmarking less appropriate.

In summary, incompleteness and delegation of decision rights favor innovation and adaptation but at the risk of damaging image consistency (Kaufmann and Eroglu 1999) and performance (Szulanski and Jensen 2008) and increasing monitoring costs. So, delegation creates a trade-off between "loss of control" for the franchisor and a positive "incentive effect" for franchisees, and this has opposing effects on residual income. The contention of this paper is that this equilibrium will determine the level of manifest conflict within the franchise system and the different propensities of franchisors and franchisees to terminate their relationship.

The study first considers several policies and requirements that are expected to prevent agency problems by providing some common knowledge and shared expectations among the partners, thus improving their fit. Specifically, we focus on procedures to curtail franchisee failure in the chain or to diminish management myopia which would lessen conflict and early terminations by both franchisor and franchisees.

Second, the paper examines franchisees' entrepreneurial autonomy in two decision areas: local advertising and pricing. Starting from the above trade-off model, we argue that franchisors and franchisees may have different perceptions regarding the appropriate level of empowerment in these decision areas. Consequently, a particular allocation of a specific decision right may have opposite effects on either side of the partnership regarding conflicts and their propensity to terminate the franchise relationship. Specifically, when decentralization is followed by a reduction in the franchisor's residual income (because of his loss of control) that exceeds the franchisees' positive incentive effects, franchisor terminations will increase while franchisee terminations will remain stable or even decrease.

\subsection{Policies aiming to reduce early terminations}

This section presents a set of policies that include franchisors' requirements to select franchisees with some prior experience, policies regarding investment obligations in physical and human capital, and the filter of franchisor experience. All of them may help to establish common, shared knowledge of business facts and practices. As long as they may reduce mistakes and misbehavior, we expect them to tend to reduce all kinds of termination, no matter who initiates them.

\subsubsection{Franchisees' prior industry experience requirements}

Franchisees terminate contracts because they do not meet their expectations. We assume that a key factor leading to this decision is outlet underperformance, although the full background picture includes other concerns such as personal circumstances and preferences. Apart from external reasons relating to competition in the marketplace, franchisee failure may also stem from wrong selection of franchisees and the resources and capabilities provided by both franchisor and franchisee.

Misconceptions impact upon future goal alignment and conflict. They come largely from inability to conduct adequate due diligence, or preinvestment screening, regarding the business concept before franchisees join the franchise chain (Weaven et al. 2010). They may also come from a propensity among franchisees to overestimate their own ability (Michael and Combs 2008) or from poor selection on the franchisor side (Frazer and Winzar 2005).

The problem is so relevant that one of the salient recommendations of Australian authorities to avoid and solve disputes was better franchisee education (Weaven et al. 2010) to be aware of possible shortcomings in the relationship.

In order to lessen the probability of these issues, some franchisors select franchisees on the basis of their business or sales ability or their knowledge of the local market and provide them with any necessary technical background (Frazer and Winzar 2005; Brookes and Altinay 2011). Many other franchisors require prior industry experience as a guarantee that prospects have baseline levels of expertise in the field (Michael and Combs 2008). In keeping with an appropriate recruitment, empirical evidence (outside franchising) shows that prior management experience may also be a strong factor in entrepreneurial success. Hence, franchisors interested in 
franchisee entrepreneurial traits may demand this experience to applicants (Gillis et al. 2011). Furthermore, the requirement of prior experience may deter low-quality franchisees from misrepresenting their abilities when searching for rents (Shane 1998). ${ }^{2}$

Weaven et al. (2010) found that the franchisees who did not appraise the franchise business concept accurately or had not objectively estimated their own capacity were more likely to take for granted unrealistic expectations of their performance. On the other hand, franchisees' prior business experience usually involves having some basic managerial skills as well as previous knowledge of the target market in which they operate (Norton 1988). Such knowledge and competences may help them to make sound judgments. Our hypothesis is therefore the following:

- H1: Requirements of prior industry experience reduce early terminations by franchisors and franchisees.

\subsubsection{Investment obligations: upfront investments and training programs}

Franchise partners' decisions to terminate the contract are also affected by the appraisal of switching costs associated with a termination compared to the potential gains derived from continuing in the relationship. When the benefits (both economic and affective) of an enduring relationship are greater, this fact may generate commitment of the partners, thus reducing early terminations (Meek et al. 2011; Kang and Jindal 2015; Mignonac et al. 2015).

We consider two sources of commitment that may play a role in reducing terminations initiated by franchisees and by franchisors: initial investment

\footnotetext{
${ }^{2}$ Experienced franchisees may also be less compliant with the chain standards because they are "set in their ways" (Lafontaine 1992) and they may have more bargaining power (Michael 2000). Moreover, experienced franchisees may have a better understanding (compared to inexperienced ones) of the operation of the business and their local markets, which increases their impulse to respond to the idiosyncratic needs of their customers and, consequently, their temptation to forego business standards (Kaufmann and Eroglu 1999). The net effect of franchisees' prior experience will reflect both positive and negative influences of previous experience on conflict. We cannot test the absence of any of these effects but only the prevalence of one over the other.
}

requirements and franchise training programs. ${ }^{3}$ First, commitment starts growing at the beginning of the relationship, when franchisees make various initial investments to enter the franchise chain that cannot be salvaged if they abandon the relationship. A few examples of such sunk costs are system identifiers, signage, store alterations, and business licenses. The value of these investments is considerably lower or even nil outside the franchising relationship and, as long as they are specific assets, they may enhance franchisees' economic commitment and thus lower their propensity to leave the relationship (Williamson 1985; Blair and Lafontaine 2005). Additionally, as initial investments increase, so do difficulties for finding new associates and set-up costs regarding franchisee replacement (Combs and Castrogiovanni 1994). From this point of view, franchisors' propensity to terminate the relationship will also decrease as the level of initial investments rises.

Second, franchisors may foster franchisees' skills with training that stimulates their knowledge, abilities, and commitment to the business. In fact, franchisors periodically train franchisees to complement their human capital, and to update business practices and routines and maintain their competitive edge (Michael and Combs 2008; Barthelémy 2008). These sessions also serve to establish personal ties and even to socialize franchisees by embedding them in the business culture (Michael 2000). They may therefore enhance franchisees' affective commitment by promoting identification with the chain's goals and values. Moreover, if this human capital is specific to the franchise chain, it also raises switching costs in the same way that initial investments do. Similarly, most of the training costs covered by the franchisor are non-recoverable (being specific to each franchisee). As a result, training programs will also increase the franchisor's switching costs, thus reducing his propensity to terminate the relationship. Therefore, our hypothesis is:

\footnotetext{
${ }^{3}$ The size of initial investments and/or the training provided to franchisees are related to the nature of the industry and the particular business model. However, even if they are not selected with the purpose of reducing disruptions, we contend that they can shape future behavior regarding terminations. As Williamson (1985) puts it, there is a "fundamental transformation" once investments are made and an ex ante competitive setting becomes an ex post bilateral monopoly where one party (franchisee) depends on the other (franchisor). We thank an anonymous reviewer for raising this point.
} 
- H2: Investments in physical and human capital (initial investments and training) reduce early terminations by franchisors and franchisees.

\subsubsection{Franchisor experience}

Franchisor experience (in chain management) may reduce terminations by producing significant learning effects that can prevent conflict and franchisees' failure. First, experienced franchisors may reduce conflict by promoting better selection of prospective franchisees. In this regard, extant literature emphasizes that appropriate selection processes have a positive effect on levels of cooperation between franchisors and their franchisees (Jambulingam and Nevin 1999; Clarkin and Swavely 2006). However, less experienced franchisors usually lack the required knowledge and capabilities needed to develop and perform effective recruitment and selection processes (Weaven and Herington 2007; Weaven et al. 2010).

Second, since older franchisors are more likely to have developed capabilities for monitoring their franchisees, ${ }^{4}$ franchising experience will also help franchisors to detect and avoid free-riding and subsequent conflict within the system (Elango 2007; Baena and Cervino 2012). Likewise, franchise experience helps to develop capabilities to better transfer system knowledge (Winter and Szulanski 2001; Holmberg and Morgan 2003; Frazer and Winzar 2005), which in turn will help the franchisees to cope with their obligations within the system and reduce tensions. In general, it may lead to adequate due diligence (Weaven et al. 2010).

At the same time, chain size can also be expected to expand as franchisors age, increasing the risk of litigation. Based on this life-cycle effect, some authors have suggested a positive influence of franchisor experience on the level of conflict and litigation within the chain (Castrogiovanni et al. 1993; Michael 2000). However, the extent to which the franchisor operates a larger number of units may also positively influence his learning opportunities (e.g., the chance to develop monitoring or selection capabilities) (Shane 1996; Elango 2007; Argyres and Bercovitz 2015). Therefore, after controlling for the size of the chain, we expect a negative net

\footnotetext{
${ }^{4}$ Note that the skills needed to monitor franchisees may differ from those needed to monitor employees in company-owned units (Shane 1996).
}

effect of franchisor experience on the probability of contract terminations.

Hence, our hypothesis is as follows:

- H3: Franchisor experience will reduce early terminations by franchisors and franchisees.

2.2 Franchisor control over pricing and advertising policies

In this section, we analyze how franchisees' autonomy in pricing and local advertising policies may affect the level of conflict and early terminations within the system. Both of these policies have been suggested by the literature to be peripheral aspects of business and suitable for delegating to franchisees (Michael 1996; Bradach 1998; Windsperger 2004; Yin and Zajac 2004; Mumdziev and Windsperger 2011; Winter et al. 2012; Ater and Rigbi 2015). Moreover, Ater and Rigbi (2015) showed that both policies might serve similar purposes. That is, franchisors may use advertising to encourage franchisees to offer particular prices even if they are not obliged formally to follow the franchisor's suggestions.

However, we argue that franchisors and franchisees may have different perceptions regarding the appropriate level of empowerment in these decision areas. Consequently, allocation of a specific decision right may have opposite effects for either side of the partnership regarding conflicts and their propensity to terminate the franchise relationship.

\subsubsection{Pricing}

Franchisors and franchisees may disagree about the prices that the franchisees charge their customers. Franchisors receive income in the form of royalties paid by franchisees. These royalties are usually calculated as a percentage of outlet revenues, so franchisors have incentives to push franchisees to implement sales strategies even if they result in lower levels of franchisee profits (Phan et al. 1996). Franchisor goals are linked to sales growth while franchisee goals are linked to both sales and profits (Dant and Nasr 1998; Holmberg and Morgan 2003). Therefore, depending on profit margins and price elasticity, franchisors can gain higher royalties with lower prices even if franchisees' profits are not increasing. Positive demand externalities and double- 
marginalization problems in franchising illustrate this conflict of interest (Blair and Lafontaine 2005).

Because of the use of a common tradename and business format, demand is positively correlated across all franchised units. In particular, the increase in demand that follows a price reduction also benefits other outlets in the system that will receive more clients. Nevertheless, since this positive externality is costly for franchisees (i.e., effects on demand at other units do not increase their individual profits), it will be underprovided. Franchisors will then have fewer customers in their company-owned outlets and, additionally, will collect fewer royalties from franchisees.

Franchisors may also face double-marginalization problems. Past research has found higher prices in franchised than in company-owned outlets (Lafontaine 1999; Lafontaine and Scott Morton 2010; Ater and Rigbi 2015) because they are able to set monopolistic prices when granted exclusive territories. That is, franchise chains are characterized by a "successive monopoly" market structure (i.e., there is market power at both the production and distribution stages). Therefore, franchisees may overprice relative to the level that maximizes chain profits (Zanarone 2009), encouraging franchisors to impose maximum resale price restraints.

Franchisors are interested in imposing not only price ceilings but also minimum resale prices. Price reductions may also involve a drawback for franchisors. Price-cutting promotions may compromise brand name value because they tempt franchisees to cut their quality to save costs while retaining their margins. Furthermore, Kalnins (2003) found that price promotions may result in intra-brand competition that does not increase the chain's market share, with new customers being attracted from other outlets belonging to the same chain instead of coming from rival brands.

It is worth noting that franchisors are not allowed to impose prices on franchisees because of antitrust laws, but they have informal means of influencing their decisions and imposing price controls, such as labels with suggested prices, rebates, and coupons. ${ }^{5}$

In summary, franchisors' residual rents are very sensitive to their franchisees' pricing freedom (insufficient sales growth, double marginalization problems, or internal price-wars with higher free-riding risks, etc.).

\footnotetext{
${ }^{5}$ Note that antitrust regulations in Europe and USA are much less severe for maximum resale prices than for minimum resale prices (Blair and Lafontaine 2005).
}

Therefore, the franchisees' positive incentive effect associated with price decentralization is not expected to compensate for the franchisor's loss of control. In hypothesis form:

- H4: Delegation of pricing is controversial; it will lead to more early terminations by the franchisor and fewer early terminations by franchisees.

\subsubsection{Local advertising}

Advertising of the franchise trademark is commonly reported as a controversial issue between franchisor and franchisees by both academics and practitioners (see Michael 1999a and the references therein), because their respective priorities differ in some regards.

Advertising benefits franchisors by providing them with increased brand awareness and demand which, in turn, will generate more royalties. However, franchisees' goals may diverge from those of the franchisor, for at least three reasons (Michael 1999a). First, even though franchisors usually collect royalties and advertising fees separately to signal that the latter are actually invested in advertising (and not used to other ends unrelated to promotion of the brand) (Brickley 1999), franchisees may not appreciate the yields of their investment and may distrust the franchisor's use of the funds. Second, franchisees demand different levels of expenditure depending on their tenure with the franchise organization because newcomers find advertising more rewarding (Dant and Berger 1996). Finally, franchisor and franchisees may disagree over the appropriate level, media, and geographic scope of the advertising, increasing the franchisees' interest in controlling advertising policies.

Franchisors are also interested in monitoring advertising because it is a way of adapting the system, since it affects the uniform identity of every unit (Bradach 1998). For instance, by centralizing advertising franchisors can encourage franchisees to follow certain systemwide promotions that are critical for the chain's image (for example, when launching new key products) (Ater and Rigbi 2015). These system-wide goals (e.g., to build and improve a national image for the brand) are usually accomplished through nationwide advertising campaigns. In this sense, it is necessary to distinguish between local advertising (promotional efforts with a short-term impact undertaken in a limited trading area) 
and national advertising (advertising efforts undertaken in the national market with a long-term impact) (Bergen and John 1997, Jørgensen et al. 2000).

In general, franchisors can protect uniformity by centralizing national advertising. Moreover, economies of scale for national image advertising usually justify such centralization (Sigué and Chintagunta 2009). At the same time, franchisors can take advantage of franchisees' local knowledge by delegating some local advertising, thus promoting the brand locally and increasing sales at the franchisee store. In fact, franchisees usually have extensive local market knowledge and proximity to the customer (Clarkin 2008), which may allow them to assess the specific messages and media that will best meet their clients' expectations.

Consequently, the positive incentive effect for franchisees (resulting from the delegation of local advertising decisions) compensates for the franchisor's potential loss of control (that can be balanced by centralizing national advertising). Therefore:

- H5: Delegation of local advertising will reduce early terminations by franchisors and franchisees.

The hypotheses are summarized in Table 1.

\section{Data collection and measurement}

We tested our hypotheses in the Spanish franchise sector. The principal data sources were the two main professional franchise guides edited in Spain (Barbadillo 2008; Tormo and Asociados 2008), which contain relevant information on 847 franchise chains. This

Table 1 Summary of hypotheses

\begin{tabular}{lll}
\hline Hypotheses & $\begin{array}{l}\text { Impact on } \\
\text { franchisee } \\
\text { terminations }\end{array}$ & $\begin{array}{l}\text { Impact on } \\
\text { franchisor } \\
\text { terminations }\end{array}$ \\
\hline H1 $\begin{array}{c}\text { Prior industry experience } \\
\text { in franchisees }\end{array}$ & - \\
H2 $\begin{array}{c}\text { Franchisee investments } \\
\text { and training }\end{array}$ & - \\
H3 $\begin{array}{c}\text { Franchisor experience } \\
\text { H4 } \begin{array}{c}\text { Franchisee autonomy on } \\
\text { pricing decisions }\end{array}\end{array}$ \\
H5 $\begin{array}{c}\text { Franchisee autonomy on } \\
\text { local advertising } \\
\text { decisions }\end{array}$ \\
\hline
\end{tabular}

information was combined with detailed primary data obtained from a mail survey sent to the franchisor firms. The questionnaires were sent to key informants who could report on our main research topic (i.e., all respondents held senior positions, such as franchising manager or CEO). ${ }^{6}$ Completed questionnaires were received from 163 franchise chains, giving a gross response rate of $19.24 \%$. However, the sample was deliberately restricted to franchisors old enough to have had early terminations, namely, with at least 4 years of continuous operation. This also allowed us to eliminate contract cancelations resulting exclusively from liabilities of newness. ${ }^{7}$ This resulted in a total of 70 usable responses with complete information.

We took several steps to minimize possible response bias. First, our measures were developed in close consultation with several experts in franchising. The questionnaire was also pretested with the managers of six chains to verify the appropriateness of questionnaire items (e.g., wording, instructions, measurement scales ...). Second, as per Podsakoff et al. (2003), the study used various procedural remedies to avoid common method bias in survey data. Specifically, the dependent (contract terminations) and independent (e.g., franchisee autonomy, training ...) variables were placed in different sections of the questionnaire; the questions were formulated as concisely as possible; different scale formats were used for certain key variables; and all participants were assured anonymity and confidentiality. In addition, a confirmatory factor analysis (CFA) approach suggests that common method bias is not likely to pose a problem for this analysis. ${ }^{8}$

\footnotetext{
${ }^{6}$ The postal questionnaire was sent out during 2008. Both primary and secondary information refers to 2008, and the 4 years that preceded the survey, so the study avoids any distortions that the 2008-2015 Spanish financial crisis might introduce in the number of early terminations.

${ }^{7}$ Liabilities of newness are problems that emerging organizations have to deal with because they have no experience in the incumbent market (Tikoo 2002). Brickley et al. (2006) contain that franchise businesses require 3 years to realize a normal return on their initial investments and they also consider that a start-up franchisor is one that has 5 or fewer years of experience. We took 4 years, the middle point value of this interval (3-5), as the threshold to consider that franchisors have a minimum amount of experience.

${ }^{8}$ In the CFA approach, all the self-reported items are modeled as the indicators of a single factor that represents method effects. Common method bias is assumed to be important if the hypothesized model fits the data. The results showed that the single-factor model did not fit the data well, $\chi^{2}=94.572(21 \mathrm{df}) ; p<0.05$; CFI $=0.779$; NFI = 0.680; $\mathrm{NNFI}=0.668 ;$ RMSEA $=0.131$. While these results do not preclude the possibility of common method bias, they do suggest that it is not of great concern in this study.
} 
Finally, comparison between respondents as per Armstrong and Overton (1977) revealed no statistically significant differences on key constructs (e.g., number of terminations, franchisee autonomy, chain size, sector) between early and late respondents. Furthermore, we tested for a potential response bias by comparing respondents and non-respondents on two key features: system size and sub-sector of activity. None of these test results showed significant differences at the 0.05 level.

\subsection{Measurement}

\subsubsection{Contract terminations}

This study considers two dependent variables, the number of contract terminations initiated by the franchisor (ZOR_Terminations) and the number of terminations initiated by his franchisees (ZEE_Terminations). Both variables take positive discrete values in the time period considered and were built on franchisor responses for the following items $^{9}$ : (i) Number of early terminations initiated by the franchisor over the last 4 years. (ii) Number of early terminations initiated by the franchisees over the last 4 years.

\subsubsection{Franchisees' business experience}

Among the independent variables, a dummy variable is used to indicate whether the franchisor requires previous business experience of the franchisee (ZEE_Experience), as in Lafontaine (1992) and Michael (2000). This variable was measured in the questionnaire by the following item: (i) Do you require your prospects to have previous experience in your industry to join the chain?

\subsubsection{Franchisees' investments in physical and human capital}

To capture the level of specific investments made by franchisees, we included two measures. (1) First, we considered the level of the franchisee's initial investment required to open an outlet

\footnotetext{
${ }^{9}$ The questions and scales included in the questionnaire are attached in an appendix.
}

(INVESTMENT) as stated in the professional guides. A franchisee's initial investment includes capital expenditure, most of which is nonrecoverable (Lafontaine 1992), on items such as upfront fee, real estate, leasehold improvements, equipment, outlet alteration and decoration, signage, uniforms, licenses, grand opening advertising and consulting, and professional fees.

(2) Second, we considered two types of franchise training programs to proxy for the franchisees' level of specific human capital and commitment. Franchisors may offer two types of training, initial training for new franchisees, and annual ongoing training programs for all franchisees (Windsperger 2004). Therefore, two possible variables were initially considered. On the one hand, Initial_Training measures the training time (in weeks) that new franchisees must undergo to join the franchise system. On the other hand, Ongoing_Training is a dummy variable that takes value 1 when current franchisees must undergo annual training programs to keep updated in new policies and procedures regarding system standards.

\subsubsection{Franchisor experience}

The franchising experience of the franchisor (ZOR_Experience) was calculated as the number of years since the franchise system was established. Since maturity or age is usually subject to a diminishing effect (Holmberg and Morgan 2003; Brickley et al. 2006; Argyres and Bercovitz 2015), we took the logarithms of the variable.

\subsubsection{Franchisees' autonomy regarding pricing and (local) advertising policies}

In order to measure this characteristic, the respondents were requested to indicate the degree of empowerment of their franchisees (based on existing authority and control over decision-making) on a five-point Likert scale adapted from Windsperger (2004) and Kidwell et al. (2007) (1 = no extent, $5=$ to a very large extent) in (1) local advertising and (2) pricing. This enabled the construction of the DELEGPricing and DELEGAdvertising variables (See Survey Appendix). 


\subsubsection{Control variables}

Two control variables were added to the model to address system size effects (ChainSIZE) and sector effects (retail-type chain). First, ChainSIZE was measured using the total number of outlets in the system. This variable controls for the influence that the number of franchisees may have on early terminations, considering that larger chains are simply more exposed to conflict (when measured as total terminations).

In addition, an industry dummy variable was used to control for the sector, RETAIL. This variable takes value 1 for retail-type chains and accounts for idiosyncrasies in retailing vs. service sectors (Windsperger 2004; Barthelémy 2008).

\section{Analytical procedure and results}

Our dependent variables, namely, the number of early terminations initiated by both franchisors ( $Z$ OR_Terminations) and franchisees (ZEE_Terminations), are limited dependent count variables which take zero or positive values (See Table 2 for a more detailed description). The classic OLS model is unsuitable for modeling count data. But linear exponential models such as the negative binomial (NB) and Poisson models provide a good alternative (See, for example, Hausman et al. 1984; Cameron and Trivedi 1986, 2013).

The simplest form of count data model is the one in which the dependent variable $\left(y_{\mathrm{i}}=\right.$ number of early terminations) follows Poisson distribution. ${ }^{10}$ This model assumes that the variable of interest $\left(y_{\mathrm{i}}\right)$ occurs at a rate $\left(\mu_{\mathrm{i}}\right)$ over a certain period of time, so that the variance of $y_{\mathrm{i}}$ is equal to the mean $\mu_{\mathrm{i}}$. Therefore, the expected number of early terminations in each period will verify that

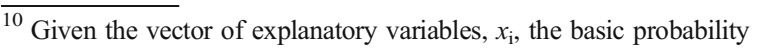
function of the Poisson distribution is $\operatorname{Prob}\left(Y_{\mathrm{i}}=y_{\mathrm{i}} \mid \boldsymbol{x}_{\mathbf{i}}\right)=\mu_{\mathrm{i}}^{y_{\mathrm{i}}} \times \frac{e^{-\mu_{\mathrm{i}}}}{y_{\mathrm{i}} !}$ for $y=0,1,2 \ldots$
}

Table 2 Frequencies of early terminations

\begin{tabular}{|c|c|c|c|}
\hline $\begin{array}{l}\text { Number of early } \\
\text { terminations } \\
\text { initiated by } \\
\text { franchisees }\end{array}$ & $\begin{array}{l}\text { Frequency } \\
(\%)\end{array}$ & $\begin{array}{l}\text { Number of early } \\
\text { terminations } \\
\text { initiated by } \\
\text { franchisor }\end{array}$ & $\begin{array}{l}\text { Frequency } \\
(\%)\end{array}$ \\
\hline 0 & $47.1 \%$ & 0 & $47.1 \%$ \\
\hline 1 & $8.6 \%$ & 1 & $20.0 \%$ \\
\hline 2 & $11.4 \%$ & 2 & $12.9 \%$ \\
\hline 3 & $7.1 \%$ & 3 & $7.1 \%$ \\
\hline 4 & $5.7 \%$ & 4 & $4.3 \%$ \\
\hline 5 & $5.7 \%$ & 5 & $2.9 \%$ \\
\hline 6 & $2.9 \%$ & 6 & $4.3 \%$ \\
\hline 7 & $1.4 \%$ & 8 & $1.4 \%$ \\
\hline 10 & $1.4 \%$ & & \\
\hline 13 & $1.4 \%$ & & \\
\hline 14 & $2.9 \%$ & & \\
\hline 15 & $1.4 \%$ & & \\
\hline 18 & $1.4 \%$ & & \\
\hline 25 & $1.4 \%$ & & \\
\hline \multicolumn{2}{|c|}{ Total observations: 70} & \multicolumn{2}{|c|}{ Total observations: 70} \\
\hline \multicolumn{2}{|c|}{ Total terminations: 201} & \multicolumn{2}{|c|}{ Total terminations: 95} \\
\hline \multicolumn{2}{|c|}{ Mean: 2.87} & \multicolumn{2}{|c|}{ Mean: 1.36} \\
\hline
\end{tabular}

Terminations are, on average, higher for franchisees than for franchisors. 95 contracts were terminated early by franchisors and 201 by franchisees over the period considered

$E\left(y_{\mathrm{i}} \mid x_{\mathrm{i}}\right)=\operatorname{Var}\left(y_{\mathrm{i}} \mid x_{\mathrm{i}}\right)=\mu_{\mathrm{i}}=e^{\beta^{\ddot{E}} \mathrm{X}_{\mathrm{i}}}$.

The equation of interest here is the rate parameter $\mu_{\mathrm{i}}$, which is the mean number of early terminations per period given the independent variables, and is formulated as:

$\ln \mu_{\mathrm{i}}=\left(\beta^{\ddot{E}} X_{\mathrm{i}}\right)$

where $i$ indexes franchise chains, $X$ is the matrix of independent variables, and $\beta$ is the vector of coefficients to be estimated (Greene 1997). Since we have two different dependent variables, ZEE_Terminations $\left(y_{\mathrm{i}}^{\mathrm{ZEE}}\right)$ and ZOR_Terminations $\left(y_{\mathrm{i}}^{\mathrm{ZOR}}\right)$, Eq. (2) must be estimated for both the mean number of franchisees' early terminations: $\mu_{\mathrm{i}}^{\mathrm{ZEE}}$ (Eq. (A)) and the mean number of franchisors' early terminations: $\mu_{\mathrm{i}}^{\text {ZOR }}$ (Eq. (B)). 
Conditional mean of franchisee terminations

$$
\begin{aligned}
\ln \mu_{\mathrm{i}}^{\mathrm{ZEE}} & =\left(\beta^{\ddot{E}} X_{\mathrm{i}}\right) \ln \mu_{\mathrm{i}}^{\mathrm{ZEE}}=\beta_{0}+\beta_{1} \text { ZEE-Experience } \\
& +\beta_{2} \text { Initial-Investment }+\beta_{3} \text { Initial_Training } \\
& +\beta_{4} \text { Ongoing_Training }+\beta_{5} \text { ZOR-Experience } \\
& +\beta_{6} \text { DelegPricing }{ }_{+} \beta_{7} \text { DelegAdvertising } \\
& +\beta_{8} \text { Retailing }+\beta_{9} \text { ChainSize }+ \text { error }
\end{aligned}
$$

Conditional mean of franchisor terminations

$$
\begin{aligned}
\ln \mu_{\mathrm{i}}^{\mathrm{ZOR}}= & \left(\beta^{\ddot{E}} X_{\mathrm{i}}\right) \ln \mu_{\mathrm{i}}^{\mathrm{ZOR}} \\
= & \beta_{0}+\beta_{1} \text { ZEE-Experience } \\
& +\beta_{2} \text { Initial-Investment } \\
& +\beta_{3} \text { Initial_Training } \\
& +\beta_{4} \text { Ongoing_Training } \\
& +\beta_{5} \text { ZOR-Experience } \\
& +\beta_{6} \text { DelegPricing } \beta_{+} \beta_{7} \text { DelegAdvertising } \\
& +\beta_{8} \text { Retailing }+\beta_{9} \text { ChainSize }+ \text { error }
\end{aligned}
$$

However, count data do not usually respect the meanvariance equality restriction (1), resulting in an overdispersion (or extra-Poisson variation) problem in the rate $\mu_{\mathrm{i}}$ (Cameron and Trivedi 1986). In our model, overdispersion would take place if the probability of one early termination within a franchise system is affected by the presence of other early terminations (i.e., if there is a lack of independence in the occurrence of early terminations for each observation). A more generalized model to account for the overdispersion problem is based on the NB probability distribution (See Hausman et al. 1984). ${ }^{11}$ To take this possibility into account, we performed a likelihood ratio test between the Poisson and the NB regressions (Cameron and Trivedi 1990) for both Eq. (A) and Eq. (B) (Table 3). The tests revealed that overdispersion exists in our count data regarding both franchisee ${ }^{12}$ and franchisor terminations, ${ }^{13}$ so we used a

\footnotetext{
${ }^{11}$ In the case of the negative binomial model the variance is not equal to the mean. Specifically, $\operatorname{Var}\left(y_{\mathrm{i}} \mid x_{\mathrm{i}}\right)=\mu_{\mathrm{i}}+\varphi g\left(\mu_{\mathrm{i}}\right)$, where $\varphi$ denotes the dispersion parameter. Once the negative binomial model is estimated, the presence of significant overdispersion is given by the significance of the $\varphi$ coefficient.

${ }^{12}$ Likelihood ratio test for NB (versus Poisson) equals $28.6(1 \mathrm{df})$, significant at $p<0.001$.

${ }^{13}$ Likelihood ratio test for NB (versus Poisson) equals 9.658 (1 df), significant at $p<0.005$.
}

NB model to estimate $\mu_{\mathrm{i}}^{\text {ZEE }}$ (Eq. (A)) and $\mu_{\mathrm{i}}^{\text {ZOR }}$ (Eq. (B)). Michael (2000: 503) explained overdispersion when considering franchise litigation because the probability of one lawsuit within the franchise system may be affected by the presence of other lawsuits. Specifically, one franchisee engaging in free-riding (quality shirking) may encourage others to do the same. At the same time, a franchisor's decision to litigate and terminate the contractual relationship with a franchisee may lower litigation costs with other franchisees. Similarly, one franchisee's decision to litigate and terminate the contract with the franchisor may encourage other franchisees to do the same (and share the costs of litigation).

\subsection{Results}

The results of the NB regressions of Eq. (A) (franchisee terminations) and Eq. (B) (franchisor terminations) are presented in Table $4 .{ }^{14}$ Means, standard deviations, and correlations among variables are reported in Table 3. The estimated equations are significant at the $1 \%$ level.

Regarding H1, contrary to our expectations, experienced franchisees seem to increase contract terminations initiated by franchisors $\left(\beta_{1}{ }^{\mathrm{ZOR}}{ }_{\text {Model B }}=0.304 *\right)$. On the other hand, franchisees' previous experience (ZEE_Experience) does not have any significant effect on early terminations initiated by franchisees. Past literature shows that franchisors do not agree on this requirement, because experienced franchisees may be more difficult to socialize or less compliant with franchisor authority (Lafontaine 1992; Stanworth and Kaufmann 1996; Frazer 2001). Specifically, our finding suggests that recruiting experienced franchisees does not have advantages for avoiding misconceptions and improving their performance and satisfaction with the franchise system. Moreover, franchisees who were familiar with the industry seemed to be more troublesome for the franchisors.

With regard to franchisees' specific investments and commitment, $\mathrm{H} 2$ predicted that by raising their switching costs or enhancing their affective commitment, franchise upfront investment (Initial_Investment) and training programs (Initial_Training and ONGOING_Training) would reduce early terminations. Our results only support this hypothesis for franchisee terminations. First, initial investment reduces early terminations initiated by franchisees

\footnotetext{
${ }^{14}$ The condition index of all predictors is below 20, as recommended by Green (1997), suggesting that multi-collinearity is not a major issue in this research.
} 


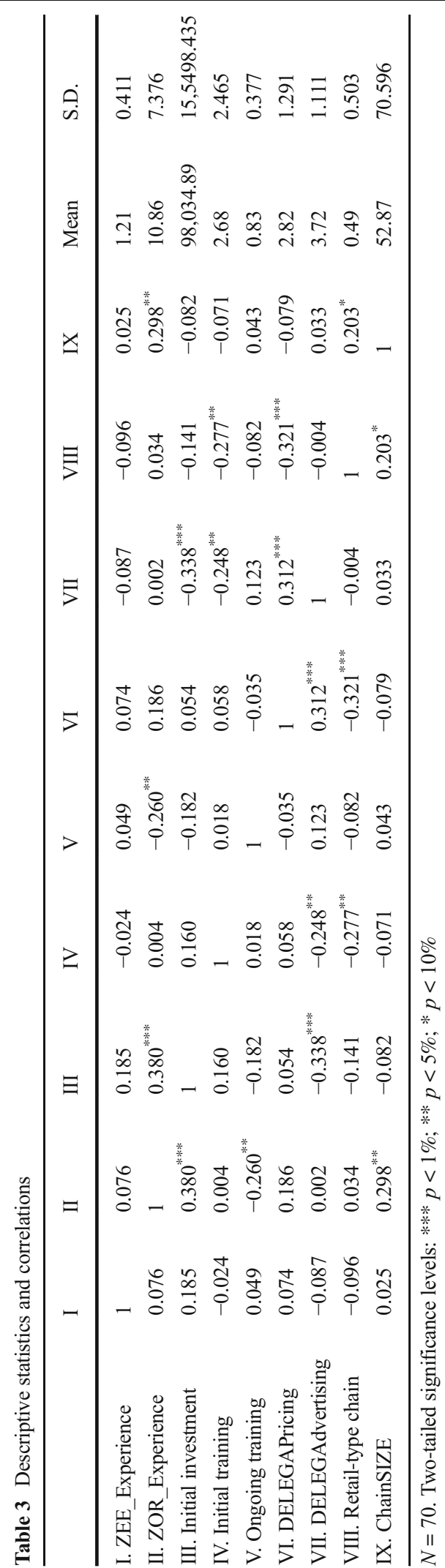

$\left(\beta_{2}{ }^{\mathrm{ZEE}}{ }_{\text {Model } \mathrm{A}}=-0.012 * * *\right)$, but this variable has no significant effect on franchisors' terminations as found by Argyres and Bercovitz (2015). This result suggests that it is contrary to the franchisees' self-interest to end the relationship when they have to make large initial investments. However, larger initial investments do not necessarily mean that (1) the franchisors' interests are better met by the franchisees (i.e., such investments will not necessarily increase franchisee's interest in pursuing system goals) or (2) the set-up costs regarding franchisee replacement are higher.

Second, while negative, the coefficient for Ongoing_Training is only statistically significant in the franchisees' model $\left(\beta_{4}{ }^{\text {ZEEs }}\right.$ Model $\left.\mathrm{A}=-1.126^{* * *}\right)$. One plausible explanation for this outcome is that ongoing training programs actually increase the level of socialization and specific human capital developed by franchisees, thus increasing their switching costs associated with termination. However, from the franchisor's point of view, such annual programs could be considered just a necessary (and costly) tool used to transfer specific or tacit know-how to their franchisees (Windsperger 2004; Barthelémy 2008). On the other hand, Initial_Training does not have significant coefficients, so offers no support for these training programs as effective tools in the prevention of early terminations.

Interestingly, accordingly to our $\mathrm{H} 3$, the franchisor's prior experience in franchising (ZOR_Experience) has a significant negative coefficient for both franchisee terminations $\left(\beta_{5}{ }^{\mathrm{ZEE}}{ }_{\text {Model } \mathrm{A}}=-1.830^{* *}\right)$ and franchisor terminations $\left(\beta_{5}{ }_{\text {ZOR }}^{\text {Model } \mathrm{B}}=-0.870 *\right)$. These results are consistent with previous qualitative studies that reported less rigorous recruitment and reduced due diligence of less experienced franchisors (Frazer and Winzar 2005; Weaven et al. 2010). Thus, learning effects in chain management seem particularly useful to franchisors and franchisees in order to prevent serious conflicts with their partners.

Results regarding variables measuring the degree of franchisee autonomy (DELEGAdvertising and DELEGPricing) confirm that franchisee and franchisor preferences about decision rights allocation may differ significantly.

Firstly, the coefficients for the variable DELEGPricing confirm H4. That is, these coefficients are significant and negative for terminations initiated by franchisees $\left(\beta_{6}{ }_{\text {ZEEs }}^{\text {ModelA }}=-0.322^{*}\right)$, and significant and positive for those initiated by franchisors $\left(\beta_{6}^{\text {ZOR }}{ }_{\text {ModelB }}=0.177^{* *}\right)$. This is a controversial 
Table 4 Regressions of early terminations in franchise systems

\begin{tabular}{|c|c|c|c|}
\hline Hypotheses & Variables & Terminations by FRANCHISEES ${ }^{\mathrm{a}}$ (model A) & Terminations by FRANCHISORS ${ }^{\mathrm{b}}$ (model B) \\
\hline- & (Constant) & $3.762(1.2745)$ & $-0.476(0.6363)$ \\
\hline H1 & ZEE_Experience (1/0) & $0.294(0.4270)$ & $0.304 *(0.1709)$ \\
\hline \multirow[t]{3}{*}{$\mathrm{H} 2$} & Initial investment $(€)$ & $-0.012 * * *(0.0410)$ & $-5.103 \mathrm{E}-7(8.6259 \mathrm{E}-7)$ \\
\hline & Initial_Training & $-0.068(0.1107)$ & $0.12(0.0307)$ \\
\hline & Ongoing_Training $(1 / 0)$ & $-1.126 * * *(0.4030)$ & $0.296(0.3218)$ \\
\hline $\mathrm{H} 3$ & ZOR_Experience (log years) & $-1.830 * *(0.8444)$ & $-0.870 *(0.4521)$ \\
\hline $\mathrm{H} 4$ & DELEGPricing & $-0.322 *(0.1643)$ & $0.177 * *(0.0816)$ \\
\hline H5 & DELEGAdvertising & $0.205(0.1814)$ & $-0.181 * *(0.0904)$ \\
\hline Control & Retail-type chain (1/0) & $0.149(0.3772)$ & $0.168(0.1766)$ \\
\hline Control & ChainSIZE & $0.007 * * *(0.0025)$ & $0.002 *(0.0009)$ \\
\hline \multicolumn{2}{|c|}{ Chi-squared test (for all zero coefficients) } & $40.495 * * *$ & $18.444 * *$ \\
\hline \multicolumn{2}{|c|}{$D$ (residual deviance) } & 71.315 & 75.339 \\
\hline
\end{tabular}

Negative binomial $(N B)$ regression of early terminations by FRANCHISEES (model A) and negative binomial $(N B)$ regression of early terminations by FRANCHISORS (model B) (conditional mean of early terminations. Standard errors in parentheses)

Notes: Sample size is 70. Significance levels are noted: $* * * p<1 \% ; * * p<5 \%$; $p<10 \%$

a) Likelihood ratio test of this model NB vs. Poisson equals $28.6(1 \mathrm{df})$. Significant at $p<0.001$

${ }^{\mathrm{b}}$ Likelihood ratio test of this model NB vs. Poisson equals 9.658 (1 df). Significant at $p<0.005$

outcome: to allow franchisees to set their own prices constitutes a significant source of conflict for franchisors. But, at the same time, this decision-making arrangement helps reduce franchisees' discontent and terminations.

Finally, the DELEGAdvertising variable has the expected significant and negative coefficient for franchisor terminations $\left(\beta_{7}{ }^{\mathrm{ZOR}}\right.$ ModelB $\left.=-0.181 * *\right)$. This result suggests that franchisors may actually benefit from franchisees' specific knowledge in developing local advertising campaigns. In contrast, the degree of delegation of local advertising decisions does not have an impact on franchisees' early terminations. So H5 is partially supported.

\section{Discussion and conclusions}

Building upon agency and resource-based theories, this work examines the antecedents of franchise terminations. The analysis highlights the influence of franchisees' entrepreneurial autonomy on terminations and reveals the main differences between franchisee and franchisor concerns in this setting.

A key finding is that there are no strong commonalities between partners (franchisors and franchisees) as regards their reactions to various antecedents of early terminations. First, we hypothesized that franchise conditions that lessen detrimental heterogeneity in terms of commitment or business acumen between both parties should not be controversial (i.e., they should prevent terminations initiated by either franchisors or franchisees). These variables are franchisee industry experience, training, initial investment, and franchisor experience in chain management.

However, franchisees' previous industry experience only has a significant and unexpected positive effect on franchisor terminations. Therefore, far from reducing conflict by realistically and appropriately shaping franchisees' ex ante expectations and adding valuable knowhow to overcome future errors, franchisees' industry knowledge seems to increase franchisor terminations. This outcome is consistent with Lafontaine (1992) who predicted that industry experience may prevent effective learning by franchisees, who will need to be re-educated. Additionally, Michael (2000) showed that previous experience of franchisees may increase litigation by enhancing franchisees' bargaining power and hindering possible agreements with franchisors. More generally, Gottschalk et al. (2017) found no advantage of habitual entrepreneurs over novice entrepreneurs in terms of survival, although those with industry experience tend to survive longer. We interpret that franchise ventures represent original templates and past industry experience does not help to disentangle the causes of business success.

Other franchise requirements such as initial investment and ongoing training programs tend to reduce franchisee 
terminations but do not affect those initiated by the franchisor. We interpret that these requirements increase the franchisees' economic and affective commitment to the chain, thus lowering the incidence of franchisees' terminations (Mignonac et al. 2015; Frazer and Winzar 2005; Meek et al. 2011). On the one hand, initial investments may bind the franchisees to the franchise relationship, delaying their exit decisions (i.e., early terminations) by raising the costs of dissolving the relationship (Kang and Jindal 2015). However, we show that they cannot reduce conflicts that end up in franchisor terminations. From this point of view, high initial investments may lead to the paradox of promoting unsatisfying but stable franchise relationships. On the other hand, ongoing training can make franchisees more socialized and better aligned with the franchisor, increasing their desire to avoid conflicts and stay in the relationship (Michael 2000). However, it can also increase the bargaining power of franchisees (i.e., they become more valuable to the franchisor) and thus intensify hold-up risks. In fact, our results suggest that this negative outcome balances out the positive socialization effect of training for franchisors, making it ineffective for preventing franchisor terminations.

The influence of the last conflict inhibitor, that is, franchise experience in chain management, suggests that franchisors that have been franchising for a longer period are able to recruit more suitable franchisees and/ or are able to develop a positive climate in the relationship, generating committed franchisees. Taking both findings regarding experience together, we observe different outcomes depending on who has gained the experience. Whereas franchisor experience reduces conflict, franchisee industry experience tends to increase the probability of franchisor terminations.

Second, our findings highlight that the entrepreneurial autonomy of franchisees has a significant and complex influence on franchise terminations. Specifically, its influence differs depending on the decision area considered and the type of termination.

Specifically, the degree of franchisee autonomy in local advertising policies produces a debatable outcome. Franchisors terminate fewer contracts when they allow franchisees to decide on local advertising. Therefore, we interpret that franchisors can capitalize on franchisees' knowledge of local markets for local advertising (Sigué and Chintagunta 2009) without incurring significant moral hazard. However, the delegation of such decision rights does not have a significant impact on franchisees' terminations. This is a puzzling result, since practitioners and past research indicate that franchisees pay great attention to advertising issues (Michael 1999a, 2014). We speculate that possible inconsistencies or asynchrony in local marketing campaigns may cause horizontal coordination problems and increase conflict among neighboring franchisees. While this drawback of decentralization does not directly affect franchisor's interests, it may overshadow the predicted franchisees' benefits of holding local advertising responsibilities, resulting in a null effect on their terminations.

Pricing is an even more controversial issue. Although antitrust laws do not allow them to impose prices, franchisors should note that they can reduce the number of terminations they initiate by centralizing pricing decisions. However, centralized pricing comes at the cost of increased probability of franchisees terminating their contracts. On the other hand, franchisors should be cautious about the consequences of delegating pricing authority for brand name value, because quality reductions tend to come after price cuts to make up for margin reductions. They therefore need to choose between monitoring franchisees more closely to prevent damaging actions (and to be aware when discounts are applied) and allowing higher franchisee exit rates.

Overall, our results help explain the sources of conflict and terminations in the franchise partnership. We provide new evidence on how different franchise provisions (such as investment obligations, training programs, and experience requirements) and different decision-making structures affect premature terminations. In addition, to our knowledge, this is the first study that empirically examines the differences in the drivers of terminations depending on who terminates the relationship. Thus, we expand the extant research by filtering the noise introduced when all terminations are studied together and provide new insights on the misalignment between franchisors' and franchisees' interests. A main contribution in this regard is to identify, for the first time, which factors can (i) increase (or prevent) terminations initiated by both franchisors and franchisees, (ii) influence only one type of termination (franchisor vs. franchisees), and (iii) prevent terminations initiated by one party while increasing those initiated by the other party. This latter category poses a major challenge regarding conflict management.

The present study also contributes to the entrepreneurial literature in various ways. First, it responds to the calls to examine the relationship between entrepreneurial autonomy (as a relevant dimension of the firm 
entrepreneurial orientation) and performance (Lumpkin et al. 2009). We analyze this relationship in the franchise setting by exploring the management dilemma of how to provide autonomy to franchisee entrepreneurs to develop their ventures whilst ensuring a homogeneous brand image for the system. In this regard, this study also responds to calls for the application of entrepreneurial dimensions to contexts that have previously not been considered (Wales et al. 2011; Audretsch et al. 2015). Namely, we expand the analysis from the firm-level to the supra-level of inter-firm partnerships (represented by franchising entrepreneurs). In doing so, instead of further exploring the positive performance outcomes linked to entrepreneurial autonomy (such as innovation and growth), our findings provide new and valuable information on its drawbacks, i.e., the role of autonomy for explaining partnership failure. Finally, we provide a more fine-grained analysis of performance outcomes by showing that the entrepreneurial autonomy of franchisees influences serious conflict and terminations differently depending not only on the type of decision area in which it is exercised (i.e., pricing vs. advertising) but also on who decides to terminate the relationship (i.e., the franchisor vs. the franchisee).

This study has important practical implications. First, our results show the importance of avoiding conflicts that lead to terminations in the franchise relationship. As the empirical tests show, terminations are not isolated, self-contained episodes. In fact, terminations present overdispersion, which means that, once the franchisor terminates a contract, he/she may find a sort of economy of scale in the process that may lead the company to terminate additional ones. Similarly, termination by one franchisee may tempt others to also terminate their contracts. These results are coherent with findings by Winsor et al. (2012) regarding conflict resilience. As these authors show, conflict has long-lasting negative impacts on franchisees that impair cooperation between partners. Further research may explore this problem in other inter-firm networks.

Our findings also highlight the tension inherent in the exercise of entrepreneurial autonomy within networks. Franchisors should be aware that whereas some franchisee initiatives reduce terminations on one side of the franchise team, they may have the opposite effect on the other (i.e., franchisee autonomy in pricing).

We also underline the need to consider whether past experience may help entrepreneurs to run their business or whether it may be counterproductive increasing tensions with franchisors that pursue a different business idea. Our study complements the findings of Gottschalk et al. (2017) in a low-tech context such as franchising relationships.

\subsection{Limitations and future research}

An important limitation of this study is that our information about terminations was provided exclusively by franchisors. In fact, it is very difficult to locate franchisees who have abandoned their systems (ex-franchisees) (Frazer and Winzar 2005). We attempted to mitigate this problem by using, whenever possible, specific and objective questions. However, future research may enrich these findings by contacting ex-franchisees.

Secondly, this study is not exhaustive in its analysis of conflict. Conflict is a dynamic process composed of a series of conflict episodes (Antia et al. 2013; Winsor et al. 2012) in which both parties may have a role. In this study, we only observe the last step in manifest and serious conflicts, namely, contract terminations. Other conflicts, not so salient as to end in terminations, may also undermine franchise performance. It may be fruitful to explore factors that could have an impact on other conflicts, even if they do not significantly influence early terminations.

An additional limitation comes from franchisee heterogeneity within franchise chains, which we do not test and which may lead to customized relationships with different franchisees. We expect that such differences are mostly limited by selection processes that search for similar franchisee profiles, although some heterogeneity may remain. For instance, our conceptualization of the decision-making structure in franchise systems does not take into account possible internal distinctions among the level of empowerment of current franchisees (e.g., single unit versus multi-unit franchisees). That is, particular franchisees with different skills (or bargaining power) may require different contractual solutions that take such differences into account. More fine-grained data on franchisee characteristics and on particular franchisor-franchisee dyads is required to address this issue. In the same vein, we do not consider how internal heterogeneity regarding franchisees' local conditions may influence the relationship between franchisees' entrepreneurial autonomy and early termination.

Finally, further research may also filter prior experience of franchisees by considering management experience in other businesses and local knowledge of the market. Our study is limited to industry experience. Research into these aspects would add significant value. 
Acknowledgements This paper has benefited from the support of the Spanish Ministry of Economy and Competitiveness (MINECO-13-ECO2013-40407R).

\section{Survey Appendix}

\section{Do you require your prospects previous experience in your industry to join the chain? \\ YES \\ NO}

To what extent are the following business decisions made by the franchisee?

\begin{tabular}{|c|c|c|c|c|c|}
\hline & Not at all & $\begin{array}{l}\text { To a slight } \\
\text { extent }\end{array}$ & $\begin{array}{l}\text { To some } \\
\text { extent }\end{array}$ & $\begin{array}{l}\text { To a } \\
\text { considerable } \\
\text { extent }\end{array}$ & $\begin{array}{l}\text { To a very } \\
\text { large extent }\end{array}$ \\
\hline Pricing & $\square$ & $\square$ & $\square$ & $\square$ & $\square$ \\
\hline Local advertising & $\square$ & $\square$ & $\square$ & $\square$ & $\square$ \\
\hline
\end{tabular}

Please, indicate below the length of the training programme provided to the franchisees:

- Training time that new franchisees must undergo to join the franchise system:

Your current franchisees must undergo ongoing training programs to maintain and/or develop the franchise business practices: $\quad$ YES $\square \quad \mathrm{NO} \square$

\section{Franchise terminations}

During the last four years some franchise agreements may have been early terminated. Please, indicate how many cancellations were instigated either by the chain or by the franchisees:

- How many franchising contracts have been terminated early during the last four years by the franchisor?

- How many franchising contracts have been terminated early during the last four years by your franchisees?.

\section{References}

Antia, K. D., Zheng, X. V., \& Frazier, G. L. (2013). Conflict management and outcomes in franchise relationships: the role of regulation. Journal of Marketing Research, 50(5), 577-589.
Arend, R. J. (2006). SME-supplier alliance activity in manufacturing: contingent benefits and perceptions. Strategic Management Journal, 27(8), 741-763.

Argyres, N., \& Bercovitz, J. (2015). Franchisee associations as sources of bargaining power? Some evidence. Journal of Economics and Management Strategy, 24, 811-832. 
Armstrong, J. S., \& Overton, T. S. (1977). Estimating nonresponse bias in mail surveys. Journal of Marketing Research, 14(3), 396-402.

Ater, I., \& Rigbi, O. (2015). Price control and advertising in franchising chains. Strategic Management Journal, 36, $148-158$

Audretsch, D. B., Kuratko, D. F., \& Link, A. N. (2015). Making sense of the elusive paradigm of entrepreneurship. Small Business Economics, 45(4), 703-712.

Baena, V., \& Cervino, J. (2012). International franchise expansion of service chains: insights from the Spanish market. The Service Industries Journal, 32(7), 1121-1136.

Bakker, R. M. (2016). Stepping in and stepping out: strategic alliance partner reconfiguration and the unplanned termination of complex projects. Strategic Management Journal, 37(9), 1919-1941.

Barbadillo. (2008). Guía de Franquicias en España. Madrid: Barbadillo.

Barthelémy, J. (2008). Opportunism, knowledge, and the performance of franchise chains. Strategic Management Journal, 29(13), 1451-1463.

Bergen, M., \& John, G. (1997). Understanding cooperative advertising participation rates in conventional channels. Journal of Marketing Research, 34(3), 357-369.

Bi, R., Davison, R. M., \& Smyrnios, K. X. (2017). E-business and fast growth SMEs. Small Business Economics, 48(3), 559576.

Blair, R. D., \& Lafontaine, F. (2005). The economics of franchising. Cambridge University Press.

Bocconcelli, R., Cioppi, M., Fortezza, F., Francioni, B., Pagano, A., Savelli, E., \& Splendiani, S. (2016). SMEs and marketing: a systematic literature review. International Journal of Management Reviews, 00, 1-28. doi:10.1111/ijmr.12128.

Bradach, J. L. (1998). Franchise organizations. Boston, MA: Harvard Business School Press.

Brickley, J. A. (1999). Incentive conflicts and contractual restraints: evidence from franchising. Journal of Law and Economics, XLII, 745-774.

Brickley, J. A., Misra, S., \& Van Horn, R. L. (2006). Contract duration: evidence from franchising. Journal of Law and Economics, 49(1), 173-196.

Brookes, M., \& Altinay, L. (2011). Franchise partner selection: perspectives of franchisors and franchisees. Journal of Services Marketing, 25(5), 336-348.

Cameron, A. C., \& Trivedi, P. K. (1990). Regression-based tests for overdispersion in the Poisson model. Journal of Econometrics, 46(3), 347-364.

Cameron, A. C., \& P. K. Trivedi (2013). Regression analysis of count data. No. 53. Cambridge University Press.

Cameron, A. C., \& Trivedi, P. K. (1986). Econometric models based on count data: comparisons and applications of some estimators and tests. Journal of Applied Econometrics, 1(1), 29-53.

Castrogiovanni, G. J., Justis, R. T., \& Julian, S. D. (1993). Franchise failure rates: an assessment of magnitude and influencing factors. Journal of Small Business Management, 31, 105-114.

Clarkin, J. E. (2008). Channel changes. An examination of ownership change in franchise firms. Journal of Marketing Channels, 15(1), 23-41.
Clarkin, J. E., \& Rosa, P. J. (2005). Entrepreneurial teams within franchise firms. International Small Business Journal, 23, 303-334.

Clarkin, J. E., \& Swavely, S. M. (2006). The importance of personal characteristics in franchisee selection. Journal of Retailing and Consumer Services, 13(2), 133-142.

Combs, J. G., \& Castrogiovanni, G. J. (1994). Franchisor strategy: a proposed model and empirical test of franchise versus company ownership. Journal of Small Business Management, 32(2), 37-48.

Combs, J. G., Ketchen Jr., D. J., \& Short, J. C. (2011). Franchising research: major milestones, new directions, and its future within entrepreneurship. Entrepreneurship Theory and Practice, 35(3), 413-425.

Dada, O. L. (2016). A model of entrepreneurial autonomy in franchised outlets: a systematic review of the empirical evidence. International Journal of Management Reviews., 00, 1-21. doi:10.1111/ijmr.12123.

Dan, S. M., \& Zondag, M. M. (2016). Drivers of alliance terminations: an empirical examination of the bio-pharmaceutical industry. Industrial Marketing Management, 54, 107-115.

Dant, R. P. (2008). A futuristic research agenda for the field of franchising. Journal of Small Business Management, 46(1), 91-98.

Dant, R. P., \& Gundlach, G. T. (1999). The challenge of autonomy and dependence in franchising channels of distribution. Journal of Business Venturing, 14(1), 35-67.

Dant, R. P., \& Berger, P. D. (1996). Modelling cooperative advertising decisions in franchising. The Journal of the Operational Research Society, 47(9), 1120-1136.

Dant, R. P., \& Nasr, N. I. (1998). Control techniques and upward flow of information in franchising in distant markets: conceptualization and preliminary evidence. Journal of Business Venturing, 13, 3-28.

Davies, M. A., Lassar, W., Manolis, C., Prince, M., \& Winsor, R. D. (2011). A model of trust and compliance in franchise relationships. Journal of Business Venturing, 26(3), 321-340.

Elango, B. (2007). Are franchisors with international operations different from those who are domestic market oriented? Journal of Small Business Management, 45(2), 179-193.

Elfring, T., \& Hulsink, W. (2003). Networks in entrepreneurship: the case of high-technology firms. Small Business Economics, 21(4), 409-422.

Frazer, L. (2001). Causes of disruption to franchise operations. Journal of Business Research, 54(3), 227-234.

Frazer, L., \& Winzar, H. (2005). Exits and expectations: why disappointed franchisees leave. Journal of Business Research, 58, 1534-1542.

Gillis, W. E., McEwan, E., Crook, T. R., \& Michael, S. C. (2011). Using tournaments to reduce agency problems: the case of franchising. Entrepreneurship Theory and Practice, 35(3), 427-447.

Gottschalk, S., Greene, F. J., \& Müller, B. (2017). The impact of habitual entrepreneurial experience on new firm closure outcomes. Small Business Economics, 48(2), 303-321.

Greene, W. H. (1997). Econometric analysis. New York: Prentice Hall.

Grünhagen, M., Wollan, M. L., Dada, O. L., \& Watson, A. (2014). The moderating influence of HR operational autonomy on the entrepreneurial orientation-performance link in franchise 
systems. International Entrepreneurship and Management Journal, 10(4), 827-844.

Hadfield, G. K. (1990). Problematic relations: franchising and the law of incomplete contracts. Stanford Law Review, 42, 927992.

Hausman, J. A., Hall, B. H., \& Griliches, Z. (1984). Econometric models for count data with an application to the patents-R\&D relationship. Econometrica, 52, 909-938.

Hendrikse, G., Hippmann, P., \& Windsperger, J. (2015). Trust, transaction costs and contractual incompleteness in franchising. Small Business Economics, 44(4), 867-888.

Holmberg, S. R., \& Morgan, K. B. (2003). Franchise turnover and failure: new research and perspectives. Journal of Business Venturing, 18(3), 403-418.

Jambulingam, T., \& Nevin, J. R. (1999). Influence on franchisee selection criteria on outcomes desired by the franchisor. Journal of Business Venturing, 14(4), 363-395.

Jørgensen, S., Sigué, S. P., \& Zaccour, G. (2000). Dynamic cooperative advertising in a channel. Journal of Retailing, 76(1), $71-92$.

Kalnins, A. (2003). Hamburger prices and spatial econometrics. Journal of Economics and Management Strategy., 12(4), 591-616.

Kang, B., \& Jindal, R. P. (2015). Opportunism in buyer-seller relationships: some unexplored antecedents. Journal of Business Research, 68(3), 735-742.

Karimi, J., \& Walter, Z. (2016). Corporate entrepreneurship, disruptive business model innovation adoption, and its performance: the case of the newspaper industry. Long Range Planning, 49(3), 342-360.

Kaufmann, P. J., \& Dant, R. P. (1999). Franchising and the domain of entrepreneurship research. Journal of Business Venturing, 14(1), 5-16.

Kaufmann, P. J., \& Eroglu, S. (1999). Standardization and adaptation in business format franchising. Journal of Business Venturing, 14(1), 69-85.

Kidwell, R. E., Nygaard, A., \& Silkoset, R. (2007). Antecedents and effects of free riding in the franchisor-franchisee relationship. Journal of Business Venturing, 22(4), 522-544.

Lafontaine, F. (1992). Agency theory and franchising: some empirical results. RAND Journal of Economics, 23(2), 263-283.

Lafontaine, F. (1999). Franchising versus corporate ownership: the effect on price dispersion. Journal of Business Venturing, 14(1), 17-34.

Lafontaine, F., \& Scott Morton, F. (2010). Markets, state franchise laws, dealer terminations, and the auto crisis. Journal of Economic Perspectives, 24(3), 233-250.

López-Bayón, S., \& López-Fernández, B. (2016). Partner empowerment and relationship failure in franchising. Journal of Small Business Management, 54(4), 1059-1079.

Lumpkin, G. T., Cogliser, C. C., \& Schneider, D. R. (2009). Understanding and measuring autonomy: an entrepreneurial orientation perspective. Entrepreneurship Theory and Practice, 33(1), 47-69.

Meek, W. R., Davis-Sramek, B., Baucus, M. S., \& Germain, R. N. (2011). Commitment in franchising: the role of collaborative communication and a franchisee's propensity to leave. Entrepreneurship Theory and Practice, 35, 559-581.

Michael, S. C. (1996). To franchise or not to franchise: an analysis of decision rights and organizational form shares. Journal of Business Venturing, 11(1), 57-71.
Michael, S. C. (1999a). Do franchised chains advertise enough? Journal of Retailing, 75, 461-478.

Michael, S. C. (1999b). The elasticity of franchising. Small Business Economics, 12(4), 313-320.

Michael, S. C. (2000). Investments to create bargaining power: the case of franchising. Strategic Management Journal, 21(4), 497-514.

Michael, S. C. (2014). Can franchising be an economic development strategy? An empirical investigation. Small Business Economics, 42(3), 611-620.

Michael, S. C., \& Combs, J. G. (2008). Entrepreneurial failure: the case of franchisees. Journal of Small Business Management, 46, 73-90.

Mignonac, K., Vandenberghe, C., Perrigot, R., El Akremi, A., \& Herrbach, O. (2015). A multi-study investigation of outcomes of franchisees' affective commitment to their franchise organization. Entrepreneurship Theory and Practice, 39, 461-488.

Mumdziev, N., \& Windsperger, J. (2011). The structure of decision rights in franchising networks: a property rights perspective. Entrepreneurship: Theory and Practice, 35(3), 449465.

Norton, S. W. (1988). Franchising, brand name capital, and the entrepreneurial capacity problem. Strategic Management Journal, 9(S1), 105-114.

Paswan, A., \& Rajamma, R. K. (2016). Franchising, knowledge transfer, and development in emerging markets. In $\mathrm{K}$. Plangger (Ed.), Thriving in a new world economy. Cham: Springer International Publishing.

Phan, P. H., Butler, J. E., \& Lee, S. H. (1996). Crossing mother: entrepreneur-franchisees' attempts to reduce franchisor influence. Journal of Business Venturing, 11(5), 379-402.

Podsakoff, P. M., MacKenzie, S. B., Lee, J. Y., \& Podsakoff, N. P. (2003). Common method biases in behavioral research: a critical review of the literature and recommended remedies. Journal of Applied Psychology, 88(5), 879-903.

Shane, S. A. (1996). Why franchise companies expand overseas. Journal of Business Venturing, 11(2), 73-88.

Shane, S. A. (1998). Research notes and communications: making new franchise systems work. Strategic Management Journal, 19(7), 697-707.

Sigué, S. P., \& Chintagunta, P. (2009). Advertising strategies in a franchise system. European Journal of Operational Research, 198(2), 655-665.

Solís-Rodríguez, V., \& González-Díaz, M. (2016). Provisions to be negotiated in franchise contracts: the case of Spanish chains. Journal of Business Administration Research, 5(2), 66-82.

Sorenson, O., \& Sørensen, J. B. (2001). Finding the right mix: franchising, organizational learning, and chain performance. Strategic Management Journal, 22(6-7), 713-724.

Spinelli, S., \& Birley, S. (1998). An empirical evaluation of conflict in the franchise system. British Journal of Management, 9(4), 301-326.

Stanworth, J., \& Kaufmann, P. (1996). Similarities and differences in UK and US franchise research data: towards a dynamic model of franchisee motivation. International Small Business Journal, 14(3), 57-70.

Street, C. T., \& Cameron, A. F. (2007). External relationships and the small business: a review of small business alliance and 
network research. Journal of Small Business Management, 45(2), 239-266.

Stuart, T. E. (2000). Interorganizational alliances and the performance of firms: a study of growth and innovation rates in a high-technology industry. Strategic Management Journal, 21(8), 791-811.

Stuart, T. E., Hoang, H., \& Hybels, R. C. (1999). Interorganizational endorsements and the performance of entrepreneurial ventures. Administrative Science Quarterly, 44(2), 315-349.

Szarka, J. (1990). Networking and small firms. International Small Business Journal, 8(2), 10-22.

Szulanski, G., \& Jensen, R. J. (2008). Growing through copying: the negative consequences of innovation on franchise network growth. Research Policy, 37(10), 1732-1741.

Tikoo, S. (2002). Franchiser influence strategy use and franchisee experience and dependence. Journal of Retailing, 78(3), 183-192.

Tormo and Asociados. (2008). Franquicias. Madrid: Selina Olmedo.

Wales, W. J., Gupta, V. K., \& Mousa, F. T. (2013). Empirical research on entrepreneurial orientation: an assessment and suggestions for future research. International Small Business Journal, 31(4), 357-383.

Wales, W., Monsen, E., \& McKelvie, A. (2011). The organizational pervasiveness of entrepreneurial orientation. Entrepreneurship Theory and Practice, 35(5), 895-923.

Weaven, S. K., Grace, D. A., Frazer, L., \& Giddings, J. (2014). Processual antecedents of perceived channel conflict in franchising. Journal of Business Economics and Management, 15(2), 316-334.
Weaven, S., \& Herington, C. (2007). Factors influencing governance choice and human resource management within services franchising networks. Journal of Management \& Organization, 13(02), 126-144.

Weaven, S., Frazer, L., \& Giddings, J. (2010). New perspectives on the causes of franchising conflict in Australia. Asia Pacific Journal of Marketing and Logistics, 22(2), 135-155.

Williamson, O. E. (1985). The Economic institutions of capitalism: firms, markets, relational contracting. Free Press.

Windsperger, J. (2004). Centralization of franchising networks: evidence from the Austrian franchise sector. Journal of Business Research, 57(12), 1361-1369.

Winsor, R. D., Manolis, C., Kaufmann, P. J., \& Kashyap, V. (2012). Manifest conflict and conflict aftermath in franchise systems: a 10-year examination. Journal of Small Business Management, 50, 621-651.

Winter, S. G., \& Szulanski, G. (2001). Replication as strategy. Organization Science, 12(6), 730-743.

Winter, S. G., Szulanski, G., Ringov, D., \& Jensen, R. J. (2012). Reproducing knowledge: Inaccurate replication and failure in franchise organizations. Organization Science, 23(3), 672685.

Yin, X., \& Zajac, E. J. (2004). The strategy/governance structure fit relationship: theory and evidence in franchising arrangements. Strategic Management Journal, 25(4), 365-383.

Zachary, M. A., McKenny, A. F., Short, J. C., Davis, K. M., \& Wu, D. (2011). Franchise branding: an organizational identity perspective. Journal of the Academy Marketing Science, 39(4), 629-645.

Zanarone, G. (2009). Vertical restraints and the law: evidence from automobile franchising. Journal of Law and Economics, 52(4), 691-692. 